\title{
"Пространственный поворот" и его интерпретация в российской науке и институциональной практике
}

Круглый стол "'Пространственный поворот" и его интерпретация в российской науке и институциональной практике" был организован по инициативе члена редколлегии нашего журнала А.Н. Демьяненко. Очная часть круглого стола была проведена 30 марта 2021 г. в Тихоокеанском государственном университете (г. Хабаровск) при участии социологов, политологов, экономистов и географов ТОГУ и ИЭИ ДВО РАН. В заочном режиме к обсуждению заявленных вопросов истории, теории и методологии обществознания присоединились представители МГИМО(У) (г. Москва) и ДВФУ (г. Владивосток). Предлагаем вниманию читателей сокращенный вариант материалов круглого стола, который, как мы надеемся, тем не менее дает представление о содержательной широте и многовекторности развернувшейся в ходе него дискуссии.

(С Бляхер Л. Е., Дельяненко А. Н., Киреев А. А., Клииенко М. В., Лалашева Ю. А., Лебедева М. М., Леонтьева Э. О., Малкова Н. Ю., Украинский В. Н., Ярулин И. Ф., Ячин С. Е., 2021

БЛЯХЕР Леонид Ефимович, д-р филос. наук, заведующий кафедрой философии и культурологии Тихоокеанского государственного университета (2. Хабаровск). E-mail: Leonid743342@mail.ru

ДЕМЬЯНЕНКО Александр Николаевич, д-р геогр. наук, главный научный сотрудник Института экономических исследований ДВО РАН (г. Хабаровск). E-mail: demyanenko@ecrin.ru

КИРЕЕВ Антон Александрович, канд. полит. наук, доцент кафедры политологии Дальневосточного федерального университета (2. Владивосток). E-mail: antalkir@yandex.ru

КЛИЦЕНкО Максим Вадимович, канд. социол. наук, доцент высшей школы "Медиа, коммуникаций и сервиса" Тихоокеанского государственного университета (г. Хабаровск). E-mail: 007756@pnu.edu.ru

ЛАМАШЕВА Юлия Александровна, канд. полит. наук, доцент кафедры социологии, политологии и регионоведения Тихоокеанского государственного университета (г. Хабаровск). E-mail: yuliya_lamasheva@hotmail.com

ЛЕБЕДЕВА Марина Михайловна, д-р полит. наук, кандидат психологических наук, заведующий кафедрой мировых политических процессов Московского государственного института меж дународных отношений (Университета) МИД России (2. Москва). E-mail: mmlebedeva@gmail.com

ЛЕОНТЬЕВА Эльвира Октавьевна, д-р социол. наук, профессор кафедры социологии, политологии и регионоведения Тихоокеанского государственного университета (2. Хабаровск). E-mail: elvira.leontyeva@gmail.com

МАЛКОВА Наталья Юрьевна, канд. филос. наук, доцент департамента искусств и дизайна Дальневосточного федерального университета (2. Владивосток). E-mail: malkova.nyu@dvfu.ru

УКРАИНСКИЙ Вадим Николаевич, канд. экон. наук, научный сотрудник Института экономических исследований ДВО РАН (2. Хабаровск). E-mail: ukrainsky@ecrin.ru

ЯРУЛИН Илдус Файзрахманович, д-р полит. наук, директор Института социально-политических технологий и коммуникаций Тихоокеанского государственного университета (2. Хабаровск). E-mail: iarulin@mail.ru

ЯЧИН Сергей Евгеньевич, д-р филос. наук, профессор департамента философии и религиоведения Дальневосточного федерального университета (2. Владивосток). E-mail: yachin.se@dvfu.ru 


\section{1. Состоялся ли, с вашей точки зрения, в современном научном по- знании "пространственный поворот"? В чем может заключаться содержание такого "поворота"?}

Киреев А.А.: По утверждениям теоретиков социо-гуманитарной науки, она переживает перманентные революционные изменения. За объявленным еще в 1960-е гг. "лингвистическим поворотом" последовали "антропологический", "культурный", "когнитивный", "натуралистический" и, наконец, "пространственный". Если все анонсированные научные повороты действительно состоялись, а их масштаб соответствовал ожиданиям заявителей, то последние полвека социо-гуманитарная наука должна была вертеться волчком.

Представляется, однако, что в реальности общая динамика современной науки была куда более спокойной. Упомянутые же "повороты", не исключая пространственного, это скорее локальные научные движения, каждое из которых охватывало лишь несколько смежных дисциплин, и притом в очень неодинаковой мере.

Говорить о "пространственном повороте", на мой взгляд, можно только трактуя его содержание в довольно узком смысле. Этот поворот, конечно, не стоит понимать как открытие социо-гуманитарной наукой пространства. Речь идет, скорее, о признании внутренней сложности этой категории. О переходе от модели однородного, пустого, стерильного пространства, постулированного классической фризикой, к картине пространства гетерогенного, анизотропного, ограничивающего распространение любого импульса и разделяющего реальность на автономные пространственные миры. Такой подход к пониманию пространства оправдан там, где оно объективно сильно и субъективно значимо диффференцировано. Именно поэтому "пространственный поворот" не универсален, а локален.

Бляхер Л.Е.: Думаю, что ответ на этот вопрос разумно начинать со второй части. Стоит отметить, что термин "поворот" приобрел сегодня столь широкое хождение, что постепенно утрачивает смысл и определенность. Имеет смысл говорить о том, что соџиальные модели сегодня существенно чаще, чем тридцать-сорок лет назад, учитывают и используют категорию "пространство". При этом сама категория "социальное пространство" тоже постепенно превращается в "зонтичное понятие", состоящее из не вполне сводимых друг с другом категорий.

Клиценко М.В.: Конечно, и до "пространственного поворота" социологи, антропологи, этнографы и, само собой разумеется, географы не пренебрегали пространством. Если принять во внимание количественный рост публикаций, начиная как минимум с рубежа 1970-х-1980-х гг., в которых в той или иной мере поднимались вопросы включения пространства в исследования самых различных социальных феноменов (урбанизация, туризм, миграции, городское и региональное планирование и т.д.), то следует признать: "пространственный поворот" действительно состоялся.

Леонтьева Э.О.: Вопрос о том, состоялся ли пространственный поворот в социальных науках предполагает в качестве своей предпосылки утверждение о существовании такого этапа, когда интереса к пространству как будто бы не наблюдалось. Позволю себе усомниться в истинности такой предпосылки и, соответственно, в состоятельности основанного на ней вопроса.

Определённое понимание пространства - явно или неявно - всегда составляло ядро любой фундаментальной теории (по крайней мере, в социологии) с самого момента её появления. Без пространства не могло бы появиться ни социальной структуры, ни стратификации. Дилемма "структура-действие", сохраняющая свою актуальность в социологии до настоящего времени, показывает, что временное и пространственное измерения в социальных науках связаны не менее крепко, чем в естественных.

Собственно, и категория пространства с самого начала XX в. становится предметом социологической рефлексии. Поэтому для социологии не было "пространственного поворота", а было последовательное нарастание интереса к пространству в течение всего времени её существования.

И тем не менее нельзя не признать, что в конце XX - начале XXI вв. пространственная тематика переживает бурный подъём, который в качестве фигуры речи получил название "поворота". 
Ламашева Ю.А.: Наличие или отсутствие внимания к категории пространства зависит в первую очередь от вида наук. В социальных и гуманитарных науках пространство уже существовало, эксплицитно или имплицитно.

Украинский В.Н.: Относительно идеи о том, что в социальных науках во второй половине XX в. произошёл так называемый "пространственный поворот", хотелось бы высказать некоторые скептические соображения.

Сам термин вышел из недр радикальной социальной мысли. Автором термина называют Э. Соджу, в работе которого "Географии постмодерна" один из параграфов получил название "Раскрытие пространственного поворота западного марксизма".

В конечном счёте "выброс" идейной связки "постмодернизм - пространственный поворот" оказался достаточно массированным: на рубеже 1990-х гг. помимо вышеуказанной книги Э. Соджи вышли ещё две работы авторитетных авторов радикального уклона: "Состояние постмодерна" Д. Харви и "Постмодернизм" Ф. Джеймисона.

В использовании термина "пространственный поворот" (со временем он всё чаще стал фригурировать в англоязычных текстах с большой буквы "П" - Spatial turn) угадывается некоторое лукавство. О чём говорят, в частности, некоторые из тезисов Э. Соджи, характеризующие вклад в пресловутый "поворот" М. Фуко: "...только Лефевр и Фуко открыто начали радикальное переосмысление онтологических, эпистемологических и теоретических отношений между пространством и временем... В их трудах, с современной точки зрения на "Пространственный поворот", можно обнаружить ряд реконфигурационных аргументов". Если относительно значимости работ А. Ледевра особых сомнений нет, то включение в состав "пространственников" М. Фуко вызывает некоторые сомнения.

Представляется более важным то, что самим дискурсом о "пространственном повороте" (во всяком случае, когда в этот дискурс включаются "социальные" географы) оказался частично замаскирован другой, фрактически не артикулируемый феномен социальных наук: социологизация англо-саксонской географоии человека. Свидетельств этому достаточно много. В частности, целый ряд работ географов последних двух десятилетий опирается на идеи, высказанные социологами. Ссылки на А. Лефевра, М. Фуко, М. де Серто, П. Бурдьё и прочих стали если не повсеместными, то весьма частыми для англо-саксонской географической мысли указанного направления.

Возникающую трансдисциплинарность можно только приветствовать, как и обращение социологов, историков и представителей других социальных наук к географическим концепциям (что, собственно, и относят к "Пространственному повороту" в социальных науках). Впрочем, растущее число публикаций, как и увеличение частоты "междисциплинарных" ссылок совсем не свидетельствуют о свершившемся "повороте". Для этого нужно оперировать не абсолютными показателями и отсылками на научные авторитеты. Список последних хоть и не мал, однако при внимательном рассмотрении оказывается весьма ограниченным: два-три десятка фрамилий против многих тысяч исследователей в области социальных наук.

Возможно, оперирование ярлыком "Пространственный поворот" приносит некоторую пользу с точки зрения организации науки и самоорганизации учёных (проведение конференций и семинаров, образование "невидимых колледжей" и исследовательских сетей и т.п.). Однако прибегать к нему без соответствующих оговорок, с позиций универсализма, представляется неоправданным. Тем более если внимательный анализ покажет наличие разных маркеров "поворота" в отдельных дисциплинах и субдисциплинах. Ведь тогда закономерен будет и другой вопрос: один "Пространственный поворот" или много?

Лебедева М.М.: В международных исследованиях географическое пространство всегда было значимой категорией. Особенности расположения государства на земном шаре в течение столетий во многом определяли международные отношения. В то же время в международных исследованиях на определенных этапах отмечалось и гипертрофированное понимание географического пространства. Речь в данном случае идет о концепциях геополитики прошлых столетий, когда географический фрактор становился не просто важным, а определяющим международные отношения. 
В XXI в. ожидания некоторых исследователей относительно того, что в связи с глобализацией в международных отношениях география закончится, не оправдались, по крайней мере, полностью. Для определенных сфрер экономики (а вместе с ней и политики), например, фринансов, географические различия действительно стерлись. Однако для других областей и отраслей они продолжают оставаться значимыми. Так, природные ресурсы, сфрера транспорта, логистика предполагают оперирование геоградическими категориями. Города и субнациональные регионы, несмотря на их включение в процессы глобализации, продолжают учитывать географическое положение. Так, пограничные регионы двух стран взаимодействуют между собой, как правило, интенсивнее.

Впрочем, в XXI в. также не обошлось без гипертрофированного восприятия географического пространства. К такому восприятию, как представляется, относится попытка определения основного вектора внешней политики России. Разворот на восток, скорее, выступил метафорой. Очевидно, что в современной мировой политике все государства, а тем более ведущие, включены именно в глобальное пространство. Хотя, разумеется, можно и нужно говорить об оправданном усилении внимания к востоку в российской внешней политике по сравнению с 1990-ми гг.

В XXI в. в международных исследованиях понятие "пространство" расширилось. Наряду с географическим пространством стали разрабатываться вопросы международного информационного, образовательного (особенно с появлением Болонского процесса), культурного пространства и т.п. Одновременно получают развитие идеи трансрегионализма, предполагающие взаимодействие между интеграционными образованиями различных географических регионов. Очевидно, что такое расширение понятия "пространства" в международных исследованиях в значительной степени определялось среди прочего и "пространственным поворотом", произошедшим в науке в целом. Проблема пространства стала интенсивно обсуждаться в международных исследованиях. Так, в 2006 г. прошел IV конвент Российской Ассоциации международных исследований, тема которого была сформулирована следующим образом: "Пространство и время в мировой политике", а в 2014 г. тема Конвента Ассоциации международных исследований звучала как "Spaces and Places: Geopolitics in an Era of Globalization".

Ячин С.Е.: Я предлагаю поставить под вопрос сам "поворот" и как концепт, и как идею. Насколько оправдано одно из измерений социальной реальности выдвигать на передний план и объявлять чем-то исключительно важным? Почему нам недостаточно оставаться на "скромных" позициях экономической, политической и культурной географии, просто дополняя пространственным измерением общую картину былого или происходящего? Скептический настрой этих вопросов не означает отрицания самого фракта смещения интересов исследователей к пространствам совместного жития людей и народов, но предполагает необходимость ответить: не изменилось ли что-то в самой социальной реальности так, что пространство (порядок со-существования) стало важнее времени (порядка следования), а синхронное измерение совместной жизнедеятельности стало важнее диахронного.

Мой ответ будет положительным. Причина, по которой пространство совместной жизни стало "важнее" времени вызвана двумя взаимосвязанными тенденциями: принципиальным ростом сложности и плотности социальных процессов. Сложность заключается в том, что для обеспечения жизнеспособности социальных систем требуется согласованная (синхронная) работа всё большего числа диффференцированных агентов и институтов, каждый из которых может даже не подозревать, что он находится в пространстве социального взаимодействия. Плотность определяет такой "дефицит" пространства, что движение любого агента сразу сказывается на всех других.

\section{2. Существует ли связь между "пространственным поворотом" и пе- реходом от обществ "Модерна" к обществам "Постмодерна"?}

Киреев А.А.: Думаю, что связь "пространственного поворота" с наступлением эпохи Постмодерна существенна, но неоднозначна. С одной стороны, общество Постмодерна впервые осознало себя сложным и плюральным, и в особенности в аспекте пространства, которое стало восприниматься как пестрый 
конгломерат локальностей, мозаика самодовлеющих местных обществ. Тем самым пространство (пространства) было признано активной силой, участвующей в процессах порождения и разрушения всевозможных форм социальной жизни. С другой же стороны, что есть пространство для Постмодерна (или для его идеологов)? Оно есть пространство воображаемое, а в пределе - пространство воображения, т.е. некий внутренний объем сознания индивида или группы. Как инструмент их желаний, самоидентификаций и самореализаций, оно крайне пластично. Его гетерогенность вторична, поскольку является только проекцией человеческого разнообразия. Собственная же, объективная, гетерогенность пространства игнорируется, лишается значимости ссылками на нивелирующую глобализацию, единство мирового рынка, техническое сжатие расстояний и "смерть географии". Таким образом, материальному пространству вновь (как в классической науке) отводится роль абстрактной формы, пустой сцены, на которой люди играют в свои игры.

Бляхер Л.Е.: Если постулировать, что мы переживаем эпоху кризиса, если не краха модернистского проекта в глобальном масштабе, которое обозначается термином "постмодерн", то все, происходящее сегодня, имеет к нему отношение. В том числе обнаружение и попытка фриксации более сложной, чем прежде структуры социального пространства.

Леонтьева Э.О.: Представляется, что этот "поворот" связан не с тем, что возобновился интерес исследователей к пространству, который, как уже сказано, всегда был. "Поворот" связан с тем, что постепенно - на фоне перехода от модерна к постмодерну - граница между пространством как объектом и размещённым в нем субъектом постепенно размывалась, в связи с чем пространство к настоящему времени утратило статус условия и предпосылки социального мира и приобрело статус его конструкта.

Демьяненко А.Н.: Для меня два первых вопроса это - один вопрос. Но прежде следует договориться о словах. Нужно определиться с тем, что понимать под "постмодерном" и "поворотами"? Но тогда следует вспомнить и о "модерне" и попутно отметить, что все только что упомянутые термины отличаются многообразием их интерпретаций.

Не случайно, У. Эко отмечает: "К сожалению, "постмодернизм" - термин годный a tout faire. У меня такое чувство, что в наше время все употребляющие его прибегают к нему всякий раз, когда хотят что-то похвалить". И все-таки, наверное, правы Э. Гидденс и Ф. Саттон, когда утверждают, что модерн "характеризуется процессами секуляризации, рационализации, демократизации, индивидуализации и подъемом науки". То есть "модерн" и "постмодерн" - исторические этапы развития общества, граница между которыми приходится на 1970-е гг.

Хотя есть и иные подходы к пониманию природы "постмодерна", а следовательно, и "модерна". Так, У. Эко считал, что "постмодернизм - не фриксированное хронологически явление, а некое духовное состояние, если угодно, Kunstwollen - подход к работе. В этом смысле правомерна фрраза, что у любой эпохи есть собственный постмодернизм ...". Впрочем, тезис У. Эко можно переформулировать следующим образом: не только у каждой эпохи, но и у каждого общества есть собственный постмодерн.

Возможно, есть смысл, взяв за отправную точку анализа известную работу Ф. Джеймисона, попытаться определиться с сущностными чертами постмодерна. Итак, "Постмодернизм - то, что вы получаете, когда процесс модернизации завершен и с природой наконец-то покончено. Этот мир человечнее прежнего, но в нем "культура" стала настоящей "второй природой"". Отметим, что положение достаточно спорное, особенно в той части, что с "природой наконец-то покончено", хотя и широко распространенное.

В развитии этого тезиса следует рассматривать и следующее положение Ф. Джеймисона: "... постмодернизм ... немыслим без гипотезы о некой фундаментальной мутации сферы культуры в мире позднего капитализма, которая включает в себя существенное изменение ее социальной функции". Действительно, культура модерна, это вовсе не культура постмодерна, в том числе и политическая культура. Приведем еще одну цитату из Ф. Джеймисона: "модель политической культуры, подходящая нашей ситуации, должна будет обязательно поднять пространственные вопросы в качестве ее фундаментального организующего устремления". 
И здесь самое время перейти к собственно "пространственному повороту", который многие теоретики рассматривают в качестве доминанты постмодерна. В частности, у Д. Бахманн-Медик есть такое высказывание: "Пространственный поворот - дитя постмодерна". В свою очередь, М. Фуко утверждал: если "Великой навязчивой идеей, неотступно преследовавшей XIX в., как известно, была история", то "Сегодняшнюю же эпоху можно, скорее, назвать эпохой пространства". В конце 1980-х гг. Ф. Джеймисон, один из наиболее влиятельных теоретиков постмодернизма, выступил с лозунгом: "Всегда опространствливай!" Этот призыв к спатиализации проистекает из самой природы постмодерна, отказывающегося от преобладающей ориентированности модерна на время.

С этим следует согласиться, с одной оговоркой: если речь идет о философии и совокупности социальных и гуманитарных дисциплин. Дело в том, что, во-первых, в экономической науке "пространственный поворот" начался еще в середине XIX в. (первоначально в рамках немецкой школы от Тюнена до Лёша, которая вышла на мировую сцену в форме "региональных исследований" (У. Айзард, Ф. Перру)). В последние десятилетия эту область исследований все чаще обозначают как "пространственная экономика". Во-вторых же, есть еще и география, прежде всего география человека, которая никогда не забывала о пространстве. Более того, "начиная с XIX в. географы развивали концепцию региона, которая позднее послужила основой для пространственных исследований".

И здесь следует попытаться понять, что есть "повороты" в социально-гуманитарных науках. Если обратиться к, наверное, лучшей на сегодня сводке по "поворотам", а именно к монографии Д. Бахманн-Медик, то там можно найти следующее: "В любом случае ... "повороты", вводя новые идеи и категории, меняя направления и модифицируя теории, являются знаменательным явлением - как в их собственных контекстуальных связях, так и с позиций реструктуризации "научного поля" в науках о культуре и обществе".

Действительно, "реструктуризация научного поля" наук о культуре сопровождалась преодолением дисциплинарных границ, иначе говоря, формированием научных сообществ, осуществляющих междисциплинарные исследования. Однако более значимо то, что поворот предполагает не просто появление новых (междисциплинарных) объектов исследования, но появление новых его инструментов. Это, как минимум, попытка создания теоретических моделей объяснения таких социальных феноменов (урбанизация, туризм и пр.), которые не укладываются в границы традиционных дисциплин. И разумеется, что "повороты" вовсе не обладают качеством абсолютной новизны: как правило, они оказываются не более, чем обновлением давно практикуемых направлений исследований.

Наконец, попытаемся сформулировать отличительные черты "пространственного поворота". Во-первых, имел место принципиальный отход от отождествления пространства с территориальностью. Во-вторых, активную роль в развитии "поворота" сыграли представители "географоии человека", по большей части "неомарксисты": Д. Харви, Э. Соджа, Д. Грегори, Д. Мэсси. Именно в работах этих исследователей, как и их многочисленных последователей, мы находим установки на изучение реальных социальных практик пространственных структур. Иначе говоря, представители "геоградии человека" в ходе "пространственного поворота", в немалой мере ими инициированного, во все большей мере стали использовать не только инструментарий, но и целый ряд идей и концепций из социологии, антропологии и культурологии. В свою очередь, "география человека", прежде всего через посредство районной концепции, а также территориальных комплексов (ландшафтов) и пространственно-временной географии, сама оказала существенное влияние на упомянутые дисциплины. В-третьих, в социальных науках "пространственный поворот" сопровождался появлением теорий и эмпирических исследований, демонстрирующих, что не только социальные отношения пространственно организованы, но и что имеет место и обратное действие. Раз возникнув, пространственные структуры оказывают обратное влияние на социальные отношения. При этом и само пространство, и образующие его элементы не только находятся в движении, но и в этом движении переплетаются друг с другом. 
Ячин С.Е.: Я, вслед за Ю. Хабермасом, склонен полагать состояние постмодерна как незавершённый проект модерна. Модерн, поставив перед собой задачу перманентной модернизации всех сфрер и обстоятельств социальной жизни, с неизбежностью столкнулся с тем, что невозможно предложить общий и устраивающий всех проект. Проект распался на множество частных "ризомных" проектов, их детерриторизацию, номадическую мобильность и пр. Для описания такого состояния "Множественности" идея пространства более органична, нежели идея целенаправленного процесса. Впрочем, постмодерн - это временное состояние неопределенности, которое может быть "снято" геометризацией возникшей трудности, т.е. акцентированием внимания к векторному характеру пространства движений.

\section{3. Наблюдаете ли вы "пространственный поворот" в российской науке?}

Киреев А.А.: Постмарксистское броуновское состояние российской социо-гуманитарной науки к общим поворотам не предрасполагает. Пока она находится в затянувшейся фразе самоорганизации, формирования научных школ и предметно-методологических направлений. Только оформившись и осознав себя, эти школы и направления смогут решать, куда (и нужно ли) им поворачивать. При этом главными мотиваторами таких решений будут (как хотелось бы верить) все-таки не прочитанные книги зарубежных коллег, а объективно довлеющие условия жизни нашего общества. Гетерогенность российских пространств рано или поздно должна вынудить отечественных социологов, политологов и фрилософров увидеть в ней не только тривиальный эмпирический факт, но и свою теоретическую и методологическую обязанность. Лишь когда масштабные прикладные исследования потянут за собой фундаментальные, в российской науке произойдет подлинный, а не эпигонский и умозрительный "пространственный поворот".

Бляхер Л.Е.: В общественных науках за последние десятилетия сложились вполне солидные и признанные исследовательские центры, акцентирующие свое внимание на социальном пространстве. Однако до настоящего времени остается "зазор" между уровнем теоретической редрлексии и описанием конкретного кейса. Последние явно уступают в распространенности первым. Видимо, когда эти две части придут в соответствие друг с другом, можно будет утверждать фокт "пространственного поворота". Пока же он тоже остается метафророй.

Клиценко М.В.: В российской науке пространственный поворот обусловлен, скорее, реакцией на труды зарубежных исследователей, в том числе А. Лефевра, Д. Харви, П. Бурдье и др., чем собственным развитием российской науки. Хотя нельзя отрицать роста интереса со стороны социологов и антропологов к исследованию, скажем, городских пространств.

Ярулин И.Ф.: "Пространственный поворот" в российских реалиях стал поворотом лицом к региональным проблемам. Одна из наиболее осмысленных исследовательских моделей опирается на комплекс природных, экономических, культурных и других признаков, который может объединять несколько различных округов или существовать внутри одного из них, но тем не менее представляет собой определенную культурно-хозяйственную целостность на основе устойчивых связей, общих представлений, образа жизни, исторических традиций. Такой вот "пространственный поворот" произошел...

Демьяненко А.Н.: Да, и касается это не только наук о культуре, но и социально-экономической географиии, и ряда смежных дисциплин, таких как антропология, этнография, социология. Но проявляется, как всегда, по-своему. Скорее всего, прав А. Павлов: "в отечественной гуманитарной науке - и уж тем более публичном пространстве - до сих пор доминируют конкретные представления о постмодерне, которые не имеют почти ничего общего с тем, как дела обстоят на самом деле". Отчасти, эти особенности российской науки связаны с особенностями самого российского общества и его пространственной организации. Но есть и другая причина, на которую обратил внимание А.А. Киреев, в ходе нашего круглого стола, а именно: "Постмарксистское броуновское состояние российского социо-гуманитарной науки к общим поворотам не предрасполагает". И тем не менее ряд публикаций последнего десятилетия дает основание говорить, что если "пространственный поворот" в российском 
обществоведении и не состоялся, то стал как-то проявляться. Правда, и здесь есть своя особенность: российские географы-гуманитарии явно не берут на себя роль лидеров, на таковую скорее претендуют отечественные социологи и экономисты.

Малкова Н.Ю.: Если говорить об интересе к "пространственному повороту" в российской науке, то он, бесспорно, есть и представлен в большей степени в сфрере культурной географии. Здесь стоит назвать имя Дмитрия Замятина, руководителя (2004-2013) Центра гуманитарных исследований пространства Российского научно-исследовательского института культурного и природного наследия имени Д.С. Лихачёва, главного научного сотрудника Высшей школы урбанистки ВШЭ (с 2015 г.).

Но в свете обозначенной проблемы хотелось бы остановиться на одной работе, которая нам представляется интересной, поскольку выполнена была в социологическом ключе. В издательстве Socio-Logos в 1995 г. вышла книга O.Е. Трущенко "Престиж центра. Городская социальная сегрегация в Москве". Работа посвящена изучению социальных различий, неравенств, иерархий в пространственном выражении, тому, что П. Бурдье определял как занесение социальной реальности в физический мир. Сосредоточив внимание на динамике сощиального состава населения в черте Садового кольца в последней трети XX в., Трущенко показывает, как в результате длительного социального процесса было закреплено исключительное на сегодняшний день положение Центра Москвы, определившей его престиж. Автор опирался на концепцию французских социологов М. Пэнсона и М. Пэнсон-Шарло, которые рассматривают престижные адреса как специфические социальные блага - продукты городской социальной сегрегации и составные условия воспроизводства господствующих классов. Благодаря этой работе можно увидеть, что попытка построить общество всеобщего равенства оказывается невозможна, так как разрыв между господством и подчинением основополагающий. В том случае, если не работают универсальные символы господства - происхождение от благородных предков или родовое богатство, - то городская социальная сегрегация принимает скрытые, искаженные формы.

\section{4. Какое влияние на "пространственный" теоретический дискурс в социальных науках оказал А. Лефевр и его работа "Производство пространства"?}

Киреев А.А.: Не уверен, что влияние книги А. Лефевра на современные пространственные исследования само по себе было столь уж сильным. Более важен тот идейный, постструктуралистский, контекст, в условиях которого она появилась и была воспринята читателями. В конечном счете, именно данный контекст определил наиболее типичную интерпретацию концептов Лефревра. И в этой интерпретации от осторожной неомарксистской позиции автора, пытавшегося взаимообразно объяснить динамики репрезентаций пространства и практик его материального производства, не осталось, по сути, ничего. Для множества современных исследователей Лефревр стал предтечей радикального конструктивистского подхода, согласно которому индивиды и группы свободно "производят" социальное пространство прямо из недр своего воображения, не стесняя себя структурами ни базиса, ни истории, ни географрии.

Демьяненко А.Н.: Возможно, я не совсем верно понял утверждение А.А. Киреева: "... влияние книги А. Ледевра на современные пространственные исследования само по себе было столь уж сильным". Наверное, он имел в виду отечественное научное сообщество. Что же касается наших зарубежных коллег, то, во-первых, они отдают должное Лефевру, как одному из пионеров (или, точнее, - предтече) "пространственного поворота". Во-вторых, многие положения, сформулированные Лефевром, причем не только в "Производстве пространства", но и в целом ряде его работ как до, так и после публикации этой монографии, по-прежнему актуальны не только у него на родине, но и далеко за ее пределами.

Здесь следовало бы детально и подробно рассмотреть и саму монографою, и основные направления ее воздействия на современников, но есть пределы "пространства" выделенного в журнале на данный круглый стол, поэтому ограничусь цитатой от $Ф$. Джеймисона: "Акцент Лефевра на пространстве 
служил не просто исправлению (модернистского) перекоса; им также признавалась растущая роль ... города как такового и новой глобальности системы. В самом деле, Лефевр призывал к новому пространственному воображению, способному подойти к прошлому по-новому и прочесть его менее очевидные секреты по шаблону его пространственных структур ... по Ледевру, любые способы производства не просто организованы пространственно, они еще и задают различные способы "производства пространства"".

Клиценко М.В.: На мой взгляд, влияние "Производства пространства" А. Лефревра на теоретический дискурс в социальных науках осуществлялось по трем направлениям:

- производство пространства есть воспроизводство общественных производственных отношений;

- существует механизм перехода от природного пространства к более сложным социальным пространствам; то есть нет монолитного социального пространства, но есть ансамбль социальных подпространств;

- социальная основа пространства заставляет смещать исследования в сторону повседневной жизни человека.

Бляхер Л.Е.: Безусловно, фигура такого масштаба, как А. Ледевр, повлияла на все грани социальных наук, в том числе и на "пространственный дискурс", породив целую волну исследований, прежде всего, в области городского пространства, но не только. В чем это влияние? В первую очередь в попытке распространения классических экономических моделей, прежде всего марксистских и неомарксистских, на область пространственных исследований. Это позволило через заимствование значимых научных концептов, метафрорически переосмысленных в связи с категорией "пространство", в какой-то момент спасти пространственные исследования от полного превращения в чистую спекуляцию, стало формой возврата к реальности. В то же время говорить об исключительной роли Лефевра в разработке этой категории представляется излишним.

Украинский В.Н.: Ограничусь тем, что приведу мнение Э. Соджа, которое я разделяю в полной мере, назвавшего А. Лефевра фрранцузским "метафрилософом", "который был более влиятельным, чем любой другой учёный, в открытии и исследовании безграничных измерений нашей социальной пространственности".

\section{5. В чем вы видите ключевые особенности структуры социального пространства? Каковы его взаимоотношения с пространством природным?}

Киреев А.А.: Природное и социальное пространства различны субстанционально. Первое состоит из физических объектов и процессов, второе - из артефрактов и практик. Но основной принцип их структурной организации един - это неравномерность: в первом случае - как неравная плотность элементов пространства, во втором - как их неравная ценность, общественная значимость. При стихийном взаимодействии природного и социального пространства они тяготеют к структурной изомордности: неравномерность второго с некоторой погрешностью воспроизводит неравномерность первого (как правило, усиливая ее). Однако, поскольку стабильность и целостность социальных систем требуют ограничения неравенства, то им присуща тенденция к выравниванию, сглаживанию экстерриториальных и территориальных различий. При этом средством исправления "несправедливой" кривизны социального, а вслед за ним и фризического пространства также служит целенаправленное внесение в него неравенства, но неравенства "правильного", "полезного", оправданного благом социальной системы в целом. Такое преодоление "плохой" неравномерности посредством неравномерности "хорошей", по сути, лежит в основе любой политики территориального, регионального развития, в своей последовательной форме идущей от социального пространства к его природному субстрату.

Бляхер Л.Е.: Природные элементы, созданные человеком артедакты и просто социальные установления (правила игры) входят в социальное пространство в тот момент, когда подвергаются наделению социальными смыслами. Они предполагают в данном пространственном локале какие-то виды деятельности или коммуникации, какие-то делают нежелательными, а то и 
невозможными. В этом плане "природное пространство", безусловно, связано с социальным. Но стоит отметить, что само понимание каких-то пространственных элементов в качестве природных тоже является продуктом социального конструирования.

Леонтьева Э.О.: Начиная с середины XX в. всё более громко заявляет о себе идея о том, что пространство не является чем-то пред-данным субъекту, нейтральным и объективным. Безусловно, природную основу никто не отменил, но её естественные границы были сужены до минимума. Пространство теперь создаётся, конструируется, получает смыслы, значимость и ценностные коннотации от субъекта. Такое пространство и называется социальным. Именно этот тезис - конструирования пространства - является ключевым и у А. Лефевра, приобретая артикуляцию в марксистской терминологии как "производство".

Из этого следует два принципиальных тезиса, раскрывающих то, в чём именно состоит "пространственный поворот". Во-первых, "пространственный поворот" означает, что социальное пространство уже не является ни результатом, ни продуктом, ни фактом, а только бборлой конструирования/производства. Во-вторых, это значит, что для социальных наук пространство выполняет фрункцию инструмента, который воспроизводит такие формы. В терминологии А. Лефевра это звучит так: "...пространство, знание и действие играют активную роль внутри существующего способа производства". И далее следует важный тезис: "...пространство работает".

Демьяненко А.Н.: Признав, в качестве "изначального предположения: (социальное) пространство есть (социальный) продукт" в "Производстве пространства" Лефевр выстраивает программу исследовании социального пространства, (которая, по моему мнению, все еще не потеряла актуальности) включающую следующие импликации:

"Первая импликация: пространство-природа (физическое) все больше отдаляется. Необратимо. Конечно, оно было и остается общей отправной точкой: истоком, origo социального процесса, быть может, основой любой "оригинальности"'. Увы, но природное (физико-географрическое) пространство как источник разнообразия пространства социального все еще terra incognita не только для социологов, экономистов, но и географовов.

"Вторая импликация: каждое общество ... производит некое пространство, свое пространство". Но так как общество не есть монолит, то, следовательно: социальное пространство представляет собой множество подпространств, находящихся в процессе взимопроникновения как друг с другом, так и с внешними, природными подпространствами.

Что же касается третьей импликации, то "Репрезентаиии пространства проникнуты знанием (смесью познания и идеологии), всегда относительным и меняющимся. Следовательно, они объективны, но могут быть пересмотрены". Рискну предположить: процессы трансформации российского социального пространства и его репрезентации проникнуты чем угодно, но только не результатами познания.

Четвертую импликацию А. Лефевр формулирует следующим образом: "...если есть производство и процесс производства пространства, есть и история". Что тут скажешь?

Лебедева M.M.: Понятие "социального пространства" не является широко распространенным в исследованиях по международным отношениям и мировой политике, особенно в России. Тем не менее в ИМЭМО РАН в 2010х гг. обратились к данной проблематике. В монографии И.Л. Прохоренко анализируются подходы к пониманию социального пространства в различных социальных науках, в том числе мировой политике и рассматривается кейс Европейского союза (Прохоренко И.Л. Пространственный подход в исследованиях международных отношений. М.: ИМЭМО, 2015).

Представляется, что в современном мире социальное пространство весьма слабо связано с природным пространством. Более важными являются исторические, культурные, социальные фракторы и соответствующие пространства. Если в прошлом природные барьеры (горы, реки, пустыни и т.п.) являлись преградами к формированию социальных пространств на территориях, разделяемых ими, то сегодня, благодаря современным технологиям, эти барьеры легко преодолеваются. Например, в условиях пандемии covid-19 при 
разрыве фризических пространств социальные пространства, хотя и пострадали, но продолжали фонкционировать и даже создавались новые, в том числе такие, как пространства солидарности врачей, помощи пожилым людям и т.п.

Насколько целесообразен "пространственный поворот" в мировой политике и международных отношениях? Представляется, что в этой области различные виды социальных пространств в значительной степени все-таки так или иначе связываются с географическим пространством. Например, на основе Болонского процесса по итогам Будапештской конференции 2010 г. было принято решение о формировании Европейского пространства высшего образования, которое в настоящее время включает в себя как европейские государства, так и центральноазиатские (Казахстан). В иных случаях, не связанных с фризическим пространством, понятие "пространство", скорее, выступает метафорой.

Ячин С.Е.: Требует прояснения онтологический смысл самой категории пространства. Только тогда нам станет понятно, как возможно представление символических (социальных) пространств в размерности фозического (метрического) пространства и почему символическое может оседать в метрическое. Научное естествознание стало теоретическим благодаря т.н. "геометризации природы" и открытию принципов аналитической геометрии (в основном это заслуга Декарта). Вся фризика до сих пор основана на этом аналитическом методе представления движения тела в многомерных пространствах. Нечто подобное для описания социальной мобильности предложил П. Сорокин, однако до сих пор такое аналитическое видение социальных процессов остается на самом начальном уровне. Геометризация - это не просто наша выдумка (абстракция от реальности). Пространство есть репрезентация силы, принуждающая существовать вещи в одном пространстве. Именно то, что за категорией пространства стоит сила - это и делает возможным системное единство сил разного рода.

Заметим, что привычные слова - "экономическое, культурное, образовательное и пр. пространства" - больше воспринимаются как метафоры, нежели как аналитические категории. Но только тогда, когда такого рода "пространства" будут пониматься как способ аналитического описания движения социальных агентов, тогда это понятие приобретёт строгий теоретический смысл. Понятие пространства воспринимается метафорически, поскольку эмпирически мыслится по аналогии с обыденным представлением о движении тел в естественной среде. Но уже теоретическая фризика понимает пространство преимущественно как векторное. Если социальные науки пойдут в том же направлении, то тогда перед ними откроется возможность представления мобильности социальных субъектов и агентов в многомерном социальном пространстве, где каждый вектор будет означать особое, рефлексивно полагаемое измерение деятельности, как сила, движущая агента в том или ином направлении.

Отношение социальных и фризического пространств остается пока недостаточно проблематизированным. Мы понимаем, что социальное (символическое) оседает в фризическое, отображается на нем. Но что является основанием их единства, которое и позволяет осуществиться этому процессу? Здесь и следует обратить внимание на концепт, который принадлежит к разряду феноменологических открытий современной философии. Этим концептом является Со-бытие. Событие снимает оппозицию пространственного и временного измерения бытия, устанавливая (предположительно) приоритет порядка сосуществования над порядком следования. Оседание символического в физическое - это и есть событие: фрактическое событие геометризации социального.

Таким образом, мы стоим перед возможностью геометризации всей социальной реальности и эта перспектива гораздо более радикальна, чем пространственный поворот в социальных науках.

На сегодняшний день наиболее близкими к геометрической модели социального являются те социальные теории, которые концептуализируют понятие сети (например, акторно-сетевая теория Б. Латура). Социальная сеть - доступное для эмпирического исследования пространство взаимодействия множества агентов. 


\section{6. Какую роль в трансформации социального пространства играют формальные и неформальные институты?}

Киреев А.А.: Институты общества, вне зависимости от степени их формализации, конституируют структуру его социального пространства. Поэтому любая трансформация социального пространства должна начинаться с институциональных преобразований. Только не нужно отождествлять последние с принятием законов.

Бляхер Л.Е.: Постановка вопроса предполагает, что пространство выступает объектом осознанного конструирования. Думаю, что это верно только отчасти. Скажем, в этом месте дороги строятся, а в этом нет. Соответственно, этим обстоятельством определяется логика расселения, простота или сложность коммуникации и, как результат, форма социального пространства. Но гораздо более рациональным утверждением мне представляется тезис, что социальное пространство выступает результатом борьбы разных способов его конструирования. В этом случае институты (степень формализованности в данном случае не существенна) становятся инструментом "войны" за пространство. В идеальном варианте возникают общие правила игры, соответствующие реальной расстановке сил, а, значит данному социальному пространству. Но чаще мы имеем иную картину. Формулируются, как правило, властной структурой "правильные" институты. В силу их откровенной симулякровой природы формируются и неформальные институты, позволяющие "обходить" формальные. Другой вариант - деятельность прекращается, а сообщество деградирует.

Клиценко М.В.: Однозначно проследить связь формальных и неформальных институтов в трансформации российского социального пространства затруднительно уже в силу того, что практически отсутствуют эмпирические исследования взаимоотношения формальных и неформальных институтов.

Ламашева Ю.А.: Инициатива трансрормации может исходить как от формальных, так и от неформальных институтов. Роль институтов и механизмы их взаимодействия зависят от ряда фракторов, индивидуальных для каждого общества.

Демьяненко А.Н.: Говоря о специфических чертах "пространственного поворота", я упустил из виду один сюжет: институты и социальное пространство. Тема эта с легкой руки А. Лефевра стала необычайно популярной и в среде урбанистов, и у представителей географии человека. Так как нет возможности рассмотреть этот сюжет подробно, то я просто зафиксирую некоторые идеи Лефевра, которые не потеряли своей актуальности.

Итак, пункт первый - "пространство не может служить априорным "условием" институтов и государства, которые его венчают. Производится ли оно как социальное отношение? Да, конечно...". В этой связи необычайно популярные в среде отечественных исследователей соображения относительно того, что российские пространства порождают сверхцентрализацию российского государства, выглядят не очень убедительно.

Пункт второй - государственный контроль (и добавим от себя - планирование), по Лефевру, "предполагает неподвижные учреждения, центры принятия решений и действия (насильственного или ненасильственного)". Но в современных обществах, как бы их ни называли, имеет место нарастание подвижности потоков не только информации, но и людей, товаров, капиталов. Как результат: "... рождается необычное, специфическое противоречие между временным и устойчивым, которое трудно разрешить централизованной власти". Поэтому, как бы ни была велика роль государства (и других формальных институтов) в преобразовании пространства, их усилий недостаточно.

И здесь мы подходим к завершающему пункту: "Преобразование общества предполагает коллективное владение и управление пространством через непрерывное участие "заинтересованных сторон" с их множественными, различными, а иногда и противоречивыми интересами". 


\section{7. Обладает ли современное российское общество и государство эф- фективными институциональными инструментами организации и управления социальным и природным пространствами?}

Киреев А.А.: Какого-то острого институционального дефицита в этой cфpepe, на мой взгляд, сегодня в стране нет. Однако по-прежнему актуальны две другие проблемы. Первая из них состоит в разреженности российских институтов развития (ИР), ведущей к их неспособности индуцировать, активизировать деятельность друг друга, порождать синергийные и кумулятивные эфрфекты. Строго говоря, корень этой проблемы даже не столько в институтах, сколько в очаговом, фрагментарном характере социально-экономического пространства, в его поглощенности и расчлененности пространством фризико-географическим. Если не разрешить, то хотя бы смягчить эту проблему могло бы планирование географической архитектуры региональных систем ИР, связывание их элементов не только в функциональные кластеры, но и в территориальные ансамбли (комплексы, коридоры, пояса).

Вторая проблема, неизбежная для всех институциональных конструкций, созданных "сверху", заключается в их малой востребованности обществом, как множеством неформально взаимодействующих акторов. Образно выражаясь, люди почему-то предпочитают ходить по газонам, а не по дорожкам, вымощенным государством. Видимо, дело в том, что при прокладке этих институциональных дорожек людей не спрашивали. Поэтому власть должна понять простую вещь - всякий набор формальных правил имеет шанс стать эдрdективным, т.е. наполниться әнергией реальных человеческих действий, лишь при условии, если его появление было не импровизацией, но ответом на явный или неявный общественный заказ.

Бляхер Л.Е.: Здесь очень много очень разных вопросов. Во-первых, общество и государство - это качественно различные сущности с разными задачами и, соответственно, разными инструментами их реализации. Во-вторых, разговор об эфффективности имеет хоть какой-то смысл, если мы изначально задали и обосновали критерии эфорективности для всех участников. И в-третьих, преобразование природных пространств (освоение), безусловно, обладает вполне отчетливой социальной составляющей.

Обживание пространства обществом идет всегда. В противном случае мы должны постулировать отсутствие общества. Вот с государством вопрос намного более сложный. Он зависит от множества параметров. В том числе от того, какое это государство и государство ли. Возможны варианты "империя", "фредерация", "полис" и т. д. с собственными стратегиями освоения/не освоения пространства. Зависит это и от того, о каком пространстве идет речь. Однако это уже другой, совершенно отдельный вопрос, требующий и отдельной редрлексии.

Клиценко М.В.: То, что государство в России обладает инструментами воздействия на социально-экономическое пространство, не вызывает сомнения. Другое дело, насколько оно эффрективно ими пользуется. Показательно, что все институциональные новации последних лет жестко привязаны к административно-территориальному делению, поэтому многие формы организации пространства (агломерации, пространственные социально-экономические системы и т.п.) просто игнорируются.

Демьяненко А.Н.: Для начала цитата из Лефевра: "Пространство большого города не поддается осмыслению по образцу предприятия (именно поэтому нельзя управлять городом по этой модели, даже осмысляя его как крупное предприятие)". Добавим, что этот тезис справедлив не только в отношении большого города, но и среднего и даже малого, а также и пространственных социально-экономических систем. Увы, но сейчас в России нет недостатка в институтах развития (здесь я полностью согласен с А.А. Киреевым), как, впрочем, и организаций, ответственных за модернизацию российских пространств. Проблема в другом. Понимание природы социального пространства предполагает многообразие знания. Конечно, правы те, кто считает, что такие знания можно получить в ходе эмпирических исследований российских пространств. Но это вовсе не означает, что можно пренебречь классикой. А "Производство пространства" - несомненная классика, которую следует читать и перечитывать. 
Ячин С.Е.: Современная Россия - это государство корпоративного типа (для которого характерно сращение власти и крупного бизнеса). Как таковое, оно в малой степени способно адекватно ответить на вызовы времени. Фактически отказавшись от федеративного обустройства своей территории, центральная власть воспроизводит "классическую" неоколониальную модель организации пространства по схеме "центр - периферия" со всеми вытекающими последствиями. Известно, что именно постколониальная эпоха (в Европе) стимулировала интерес к реорганизации пространства взаимодействия. Неоколониальная политика не требует особого искусства управления, что, собственно, и обуславливает отсутствие государственного интереса к пространственному обустройству страны.

Бляхер Л. Е., Демьяненко А. Н., Киреев А. А., Клиценко М. В., Ламашева Ю. А., Лебедева М. М., Леонтьева Э. О., Малкова Н. Ю., Украинский В. Н., Ярулин И. Ф., Ячин С. Е. "Пространственный поворот" и его интерпретация в российской науке и институциональной практике.

Blyakher L. E., Dem'yanenko A. N., Kireev A. A., Klitsenko M. V., Lamasheva Yu. A., Lebedeva M. M., Leont'eva Eh. O., Malkova N. Yu., Ukrainskij V. N., Yarulin I. F., Yachin S. E. "Spatial turn" and its interpretation in Russian science and institutional practice.

Для цитирования: Бляхер Л. Е., Демьяненко А. Н., Киреев А. А., Клиценко М. В., Ламашева Ю. А., Лебедева М. М., Леонтьева Э. О., Малкова Н. Ю., Украинский В. Н., Ярулин И. Ф., Ячин С. Е. "Пространственный поворот" и его интерпретация в российской науке и институщиональной практике // Ойкумена. Регионоведческие исследования. 2021. № 2. С. 46-59. DOI: $10.24866 / 1998-6785 / 2021-2 / 46-59$

For citation: Blyakher L. E., Dem'yanenko A. N., Kireev A. A., Klitsenko M. V., Lamasheva Yu. A., Lebedeva M. M., Leont'eva Eh. O., Malkova N. Yu., Ukrainskij V. N., Yarulin I. F., Yachin S. E. "Spatial turn" and its interpretation in Russian science and institutional practice // Ojkumena. Regional researches. 2021. № 2. P. 46-59. DOI: 10.24866/1998-6785/2021-2/4659 